\title{
COUPLING DYE TRACING, WATER CHEMISTRY, AND PASSIVE GEOPHYSICS TO CHARACTERIZE A SILICICLASTIC PSEUDOKARST AQUIFER, SOUTHEAST MINNESOTA, USA
}

\author{
John D. Barry \\ Minnesota Department of Natural Resources, 500 Lafayette Road, St. Paul, MN, 55155, USA, \\ john.barry@state.mn.us
}

Jeffrey A. Green

Minnesota Department of Natural Resources, 3555 9th Street NW Suite 350, Rochester, MN, 55901, USA,

jeff.green@state.mn.us

\section{J. Wes Rutelonis}

Minnesota Department of Natural Resources, 500 Lafayette Road, St. Paul, MN, 55155, USA,

joseph.rutelonis@state.mn.us

Julia R. Steenberg

Minnesota Geological Survey, 2609 West Territorial Road, St.Paul, MN, 55114, USA, jsteenb@umn.edu

\section{E. Calvin Alexander, Jr.}

University of Minnesota, Earth Sciences Department, 150 John T. Tate Hall, 116 Church St. SE, Minneapolis, MN, 55455,USA,alexa001@umn.edu

\begin{abstract}
A decade of dye tracing in southeastern Minnesota within shallow, buried Cambrian siliciclastic units has revealed groundwater flow characteristics more commonly associated with carbonate karst aquifers. To understand the hydrologic system, several characterization methods were used on a pair of dye traces in central Winona County in southeast Minnesota. South of the City of Stockton, Minnesota, a deeply incised north-south trending valley and its tributaries contain a number of large springs and several sinking streams. In the project area, streams sink into the lower part of the Cambrian siliciclastic Jordan Sandstone or the upper portion of the underlying Cambrian St. Lawrence Formation. The St. Lawrence Formation consists of interbedded wellcemented siltstone, very fine-grained sandstone, and very thin shale. Most of the large springs found in deeply incised valleys in southeastern Minnesota emanate from the basal St. Lawrence and upper Lone Rock Formations. The Lone Rock is a siliciclastic unit consisting of finegrained sandstone and siltstone with minor beds of shale and dolostone. Passive charcoal detectors were used to calculate dye-breakthrough velocities that ranged between 58-203 meters/day at one location and 4772 meters/day at another. These velocities are consistent
\end{abstract}

with other trace velocities measured within siliciclastic units in southeastern Minnesota. Water samples collected at the sinking streams, springs, and a domestic well in the project area show elevated nitrate and chloride concentrations indicating anthropogenic impacts likely related to application of fertilizers and road salt. Passive geophysical data were collected at the sinking stream locations and at transects within two valleys to characterize depth to bedrock. At the sinking stream above mapped Jordan Sandstone, the depth to bedrock was determined to be 6.4 meters. The depth at the location mapped above the St. Lawrence Formation was determined to be 5.2 meters. These data suggest colluvium and alluvium layers are thicker than what was previously conceptually modeled in this setting. The results of these dye traces are consistent with others in southeast Minnesota showing that the siliciclastic St. Lawrence and Lone Rock Formations have conduit-flow properties similar to those found in carbonate karst aquifers.

\section{Introduction}

Underlying southeastern Minnesota is a broad structural geological depression containing a sequence of sedimentary Paleozoic bedrock layers that are Cambrian to Devonian in age (Mossler, 2008). In Minnesota, the 
Cambrian rocks are generally dominated by siliciclastic materials and the Ordovician and Devonian rocks dominated by carbonates. These bedrock aquifers support domestic, agricultural and industrial water needs as well as more than one hundred trout streams that are fed by groundwater springs.

Decades of dye tracing in Minnesota focused on characterizing groundwater velocities and delineating groundwatersheds of the carbonate dominated Ordovician and Devonian rocks to improve groundwater management and protection in the region. In the last ten years, many hydrologic investigations in southeastern Minnesota have focused on characterizing sinking streams and groundwater flow directions and velocities in two siliciclastic dominated formations of the Cambrian system: the St. Lawrence and Lone Rock Formations (Green et al., 2008, 2012; Barry et al., 2015).

Multi-faceted characterization of secondary pore networks in siliciclastic-dominated units in southeast Minnesota that coupled outcrop and borehole geophysical observations has shown these siliciclastic units generally have bedding-parallel and vertically oriented apertures less than a few centimeters (Runkel et al., 2014). Vertically oriented apertures are likely developed from regional extension, thermoelastic contraction, or unloading associated with uplift and erosion (Underwood et al., 2003). The process by which bedding-parallel oriented apertures form remains enigmatic; recent studies suggest they appear to be mechanically developed although dissolution of interstitial carbonate cement within these units may also be a factor (Runkel et al., 2014). Although these units lack the large conduits typically associated with carbonate karst, dye tracing in these Minnesota siliciclastic units has recorded non-Darcian minimum groundwater flow velocities of 28-750 meters/day (932,460 feet/day). As a comparison, groundwater velocities in the overlying Galena-Spillville Karst System are much higher: 1.6-4.8 kilometers/day (1-3 miles/day) (Green et al., 2014).

These non-Darcian minimum groundwater flow velocities coupled with characteristic symmetric breakthrough curves with recessional limbs that last months to years warrant classifying these shallow buried siliciclastic groundwater systems as pseudokarst. Hydrologically, pseudokarst is described as “... a predominance of subsurface drainage through conduit type voids, but lack[ing] the element of long-term evolution by solution and physical erosion” (Kempe and Halliday, 1997).

This paper focuses on the geologic and hydrogeologic setting of southeastern Minnesota and describes the results of coupling dye tracing, water chemistry, and passive geophysics to characterize a siliciclastic pseudokarst aquifer in Winona County.

\section{Geologic and Hydrogeologic Setting}

In Winona County, a veneer of unconsolidated sediments that is generally less than 15 meters ( 50 feet) thick overlies sedimentary bedrock units from the Upper Cambrian through the Upper Ordovician in age (Steenberg, 2014; Lusardi et al., 2014).

A broad plateau of resistant dolostone of the lower Ordovician Prairie du Chien Group is dissected by numerous narrow valleys that ultimately drain east to the Mississippi River or south-southeast to the Root River (Figure 1). The stratigraphy underlying the Prairie du Chien is dominated by relatively easily weathered sandstone, siltstone, and shale layers of the Upper Cambrian Jordan, St. Lawrence and Lone Rock formations that form the valley slopes and floors (Figure 2).

The St. Lawrence Formation consists of wellcemented, thin-to-medium beds of siltstone, dolomitic

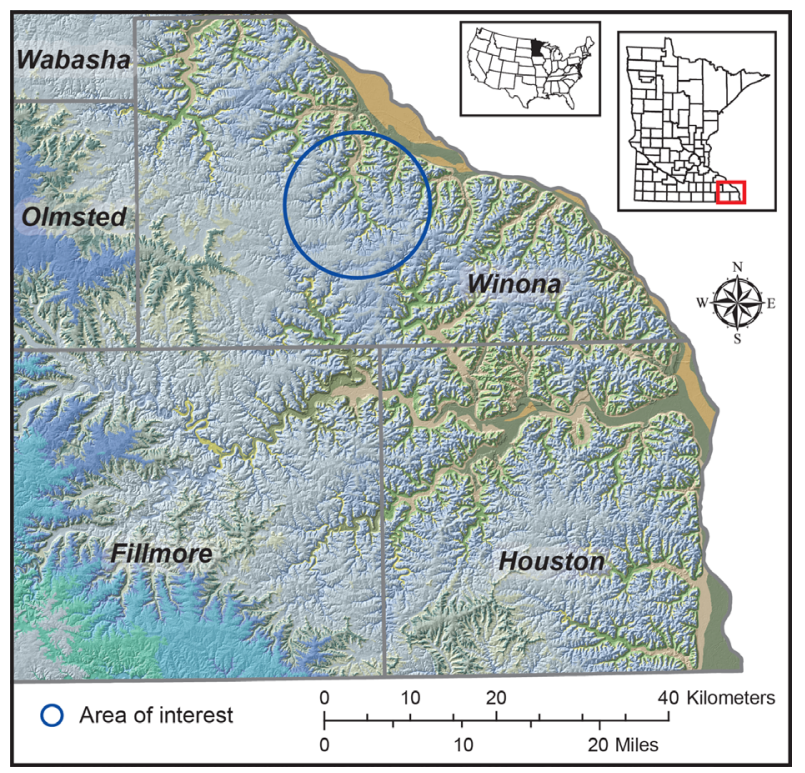

Figure 1. Study Area. Location of study area superimposed on the regional geologic setting of Paleozoic rocks in southeast Minnesota. Geologic map from Runkel et al., 2013. 


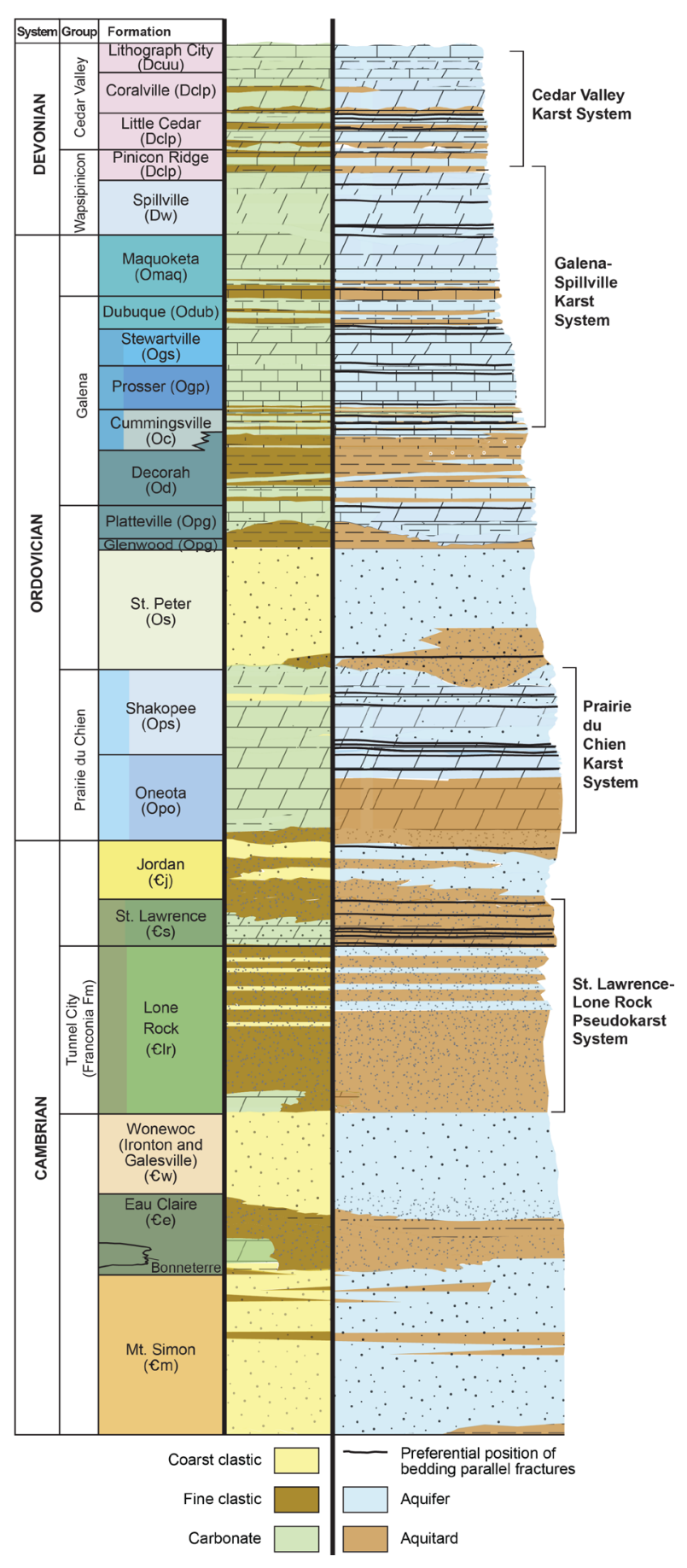

Figure 2. Geologic and generalized hydrogeologic attributes of Paleozoic rocks in southeast Minnesota. Modified from Steenberg, 2014. Regional karst system described in Runkel et al., 2013. Pseudokarst system described in Barry et al., 2015. siltstone, very fine-grained sandstone and shale. In deep bedrock settings (buried by more than 15 meters [50 feet] of overlying bedrock), the St. Lawrence has a low matrix permeability and poor connectivity of fractures in a vertical direction, leading to a low bulk vertical conductivity. However, pervasive beddingparallel secondary pore networks with high horizontal conductivity results in a marked anisotropy (Runkel et al., 2003). The low bulk vertical hydraulic conductivity for the St. Lawrence in deep settings has influenced guidance in the Minnesota Well Rules handbook, where it is classified as a confining layer (Minn. Dept. of Health, 2011). In southeastern Minnesota, the integrity of the St. Lawrence as an aquitard is diminished in shallow bedrock conditions (within 15 meters [50 feet] or less of the bedrock surface) and in the vicinity of deeply incised valleys. Vertical and bedding-parallel apertures are more abundant, better-connected and enhanced compared to deep bedrock settings. A transition from higher to lower aquitard integrity within 2,500 meters ( 8,200 feet) from eroded edges in incised tributary valleys to the Mississippi River has been estimated, using tritium and nitrate as tracers (Runkel et al., in prep).

The underlying Lone Rock Formation of the Tunnel City Group, is composed of fine-grained sandstone and siltstone with interbedded shale and dolostone (Mossler, 2008). High permeability bedding plane fractures are common in both St. Lawrence and Lone Rock, and springs are commonly found near the toe of the valley slopes emanating from each of these units. These springs supply cool isothermal water that forms the headwaters of the abundant trout streams in these valleys.

A geologic column for Winona County (Figure 2) displays both the lithostratigraphic and generalized hydrostratigraphic properties of the Paleozoic bedrock units in the county (Steenberg, 2014). Hydrostratigraphic attributes are generalized into either aquifer or aquitard using relative permeability. Layers assigned as aquifers are permeable, easily transmitting water through porous media, fracture networks, or conduits. Layers assigned as aquitards have lower permeability that vertically retards flow but may also contain high permeability bedding plane fractures that yield large quantities of water.

\section{Methods}

This investigation occurred in east central Winona County, south/southeast of the City of Stockton along 
Stockton Valley Creek and its tributaries (area I in Figure 5). The project was initiated to characterize aquifer interaction for use in water resource protection and further map groundwater springsheds. The work occurred in two areas where a series of springs supply water to a private fish hatchery.

Dye tracing was conducted using fluorescent dyes and passive charcoal receptors that were deployed prior to the introduction of the dyes and changed at variable frequencies following dye introduction. Passive charcoal detectors were deployed for 6.5 months following the introduction of dye. Flow of dye through the hydrologic system was timed and mapped based on when and where dyes were recovered from passive detectors. Analyses of the passive detectors was performed at the University of Minnesota Department of Earth Sciences Hydrochemistry Laboratory using a Shimadzu RF5000 scanning spectrofluorophotometer and Fityk version 1.20 software.

Water chemistry was characterized using direct water samples from springs, sinking streams, surface water, and a residential well in the project area that were analyzed for anions. Anion concentrations were determined using a Thermo Dionex ICS-5000+ Ion Chromatography System. Spring and surface water samples were collected under base flow conditions.

Project area chemistry was coupled with regional groundwater chemistry collected as part of sampling for the Winona County Geologic Atlas, which is a project of the Minnesota DNR County Geologic Atlas (CGA) Program (Barry, in prep). CGA chemistry includes standard field parameters, cations, anions, trace metals, stable isotopes, and enriched tritium. Inorganic chemistry was analyzed at the Minnesota Department of Agriculture Laboratory. Isotopes were analyzed at the University of Waterloo.

The Minnesota Geological Survey routinely uses horizontal to vertical spectral ratio analysis (HVSR) in their County Geologic Atlas program to inexpensively and quickly determine depth to bedrock for geologic mapping. The HVSR method uses ambient noise and relationships between sediment thickness and shear waves to estimate thickness of unconsolidated sediment over bedrock. Sediments in valleys in southeastern Minnesota often have high amplitude HVSR peaks that are representative of the strong impedance contrasts at the bedrock surface (Chandler and Lively, 2014). Depth to bedrock estimates were determined using HVSR collected using a Micromed Tromino Model TRZ tromograph and analyzed using Tromino Grilla software.

Stratigraphic interpretations of spring positions are based on the Winona County bedrock geology map. Mapping was developed using a combination of correlations to water well records from the County Well Index and field outcrop examination (Steenberg, 2014; Bauer and Chandler, 2014).

Project geospatial data including the locations of karst features, springs, and well locations are stored in parallel databases that share a relatable unique identifier. This unique identifier is used in the Minnesota Karst Feature Database (KFD), the Minnesota Spring Inventory (MSI), the County Well Index (CWI), and the Minnesota Groundwater Tracing Database (MGTD, in prep). The unique identifier is a ten character alpha-numeric field, but has been abbreviated for this report (e.g., $85 \mathrm{~B} 0000026$ is abbreviated to $85 \mathrm{~B} 26$ ).

\section{Dye Tracing Results}

Two traces were completed along Stockton Valley Creek and its tributaries. The first trace introduced 1.237 kilograms $(\mathrm{kg})$ of 35 weight percent Uranine HS dye solution into an upstream riffle and discrete sinking stream point (85B26) located within the Jordan Sandstone subcrop at the north valley location. The second trace introduced $1.199 \mathrm{~kg}$ of 33 weight percent eosine dye solution into an upstream riffle and discrete sinking stream point (85B24) located within the St. Lawrence Formation subcrop in the southern valley location. Stream discharge was estimated to be $0.001-$ 0.002 cubic meters per second $(0.04-0.07$ cubic feet per second) at the north valley pour location and $0.0012-$ 0.0015 cubic meters per second $(0.04-0.06$ cubic feet per second) at the south valley pour location.

At the north valley investigative area (Figure 3), dye was detected at a number of springs and two flowing augmentation wells associated with the fish hatchery. We were unable to review well construction records for these wells; however based on local knowledge it is believed they are roughly 15 meters (50 feet) deep or less and completed in the Lone Rock Formation. Assuming a straight-line distance from the northern 
stream sink (85B26) to the north pond spring (85A16) located at the hatchery complex, the estimated minimum peak groundwater velocity ranges from roughly 108 to 203 meters/day (354 to 665 feet/day).



Figure 3. North Valley Investigation area. Paleozoic bedrock geology, inferred dye flow paths, estimated depth to bedrock, and select chemistry for springs and surface water in the north valley investigation area. Geologic map from Steenberg, 2014.
Uranine HS additionally emerged at a spring located approximately 1,350 meters (4,430 feet) to the north (85A15). Assuming a straight-line distance from 85B26 to $85 \mathrm{~A} 15$, the estimated minimum peak groundwater velocity ranges from roughly 58 to 80 meters/day (190 to 262 feet/day). Dye recovered from the north valley trace traveled through the entire thickness of the St. Lawrence Formation and reemerged at a spring located in the mid to lower Lone Rock Formation.

At the south valley investigative area (Figure 4) dye first appeared at spring 85A29 located approximately 1,080 meters $(3,540$ feet) to the northwest of the sinking stream. Assuming a straight-line distance from the southern stream sink (85B24) to the spring, the estimated minimum peak groundwater velocity ranges from roughly 47 to 72 meters/day (154 to 236 feet/day).

Dye recovered from the south valley trace traveled through the St. Lawrence Formation, reemerging at a

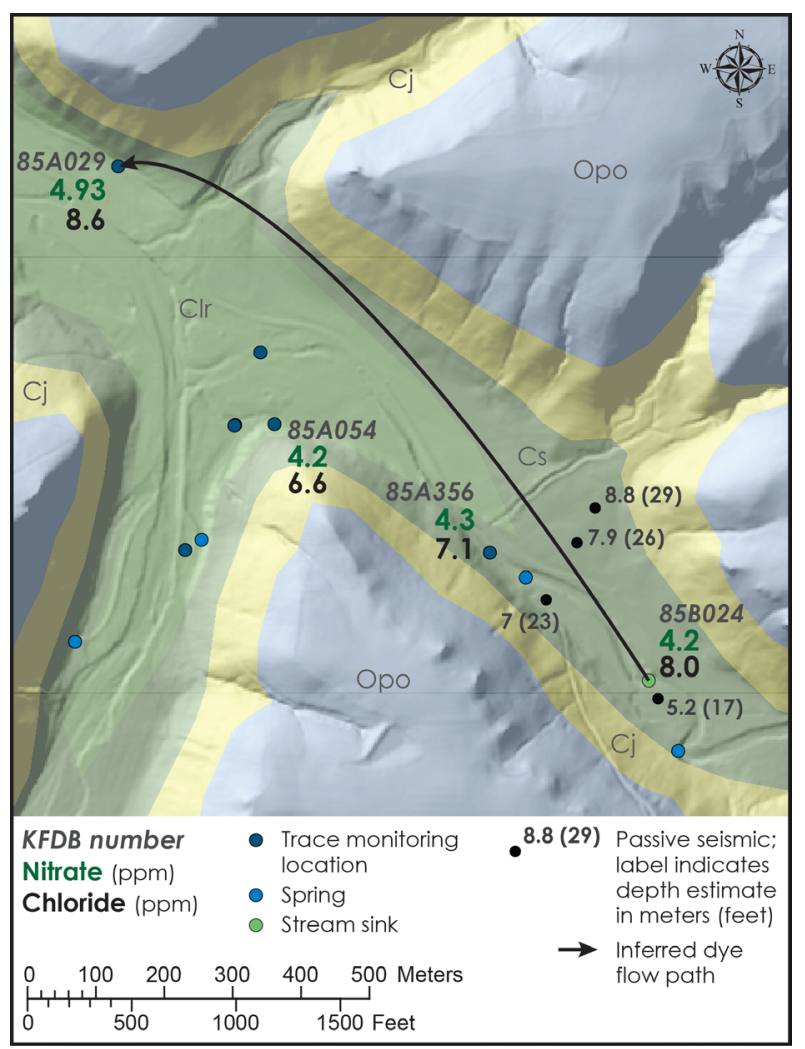

Figure 4. South Valley Investigation area. Paleozoic bedrock geology, inferred dye flow paths, estimated depth to bedrock, and select chemistry for springs and surface water in the south valley investigation area. Geologic map from Steenberg, 2014. 
spring located near the contact of the basal St. Lawrence and Lone Rock Formations. Dye was also later detected at two passive detectors located at downstream surface water locations. These detects are consistent with direct surface water flow during high flow events or possibly hyporheic flow through streambed materials.

Previous traces have occurred in the vicinity (Figure 5). A trace was conducted in the early 1980s, east of the project area, at the Murphy landfill location (Dalgleish and Alexander, 1984, area III in Figure 5). In 2014-2015, traces were conducted to the north-northwest near the City of Stockton (Barry and Green, 2015, area II in Figure 5).
The 2014-2015 Stockton vicinity traces occurred in the same siliciclastic units as these traces and determined minimum groundwater velocities of 28 to 127 meters/day (93 to 415 feet/day), similar to those determined from this work. The Murphy landfill trace was initiated in carbonate karst of the Prairie du Chien Group.

\section{Water Chemistry Results}

Standard field parameters were collected for water samples collected as part of these traces in the north and south valleys. Samples were analyzed for anion chemistry. Project samples were compared to regional groundwater samples collected in 2015 and 2016 at

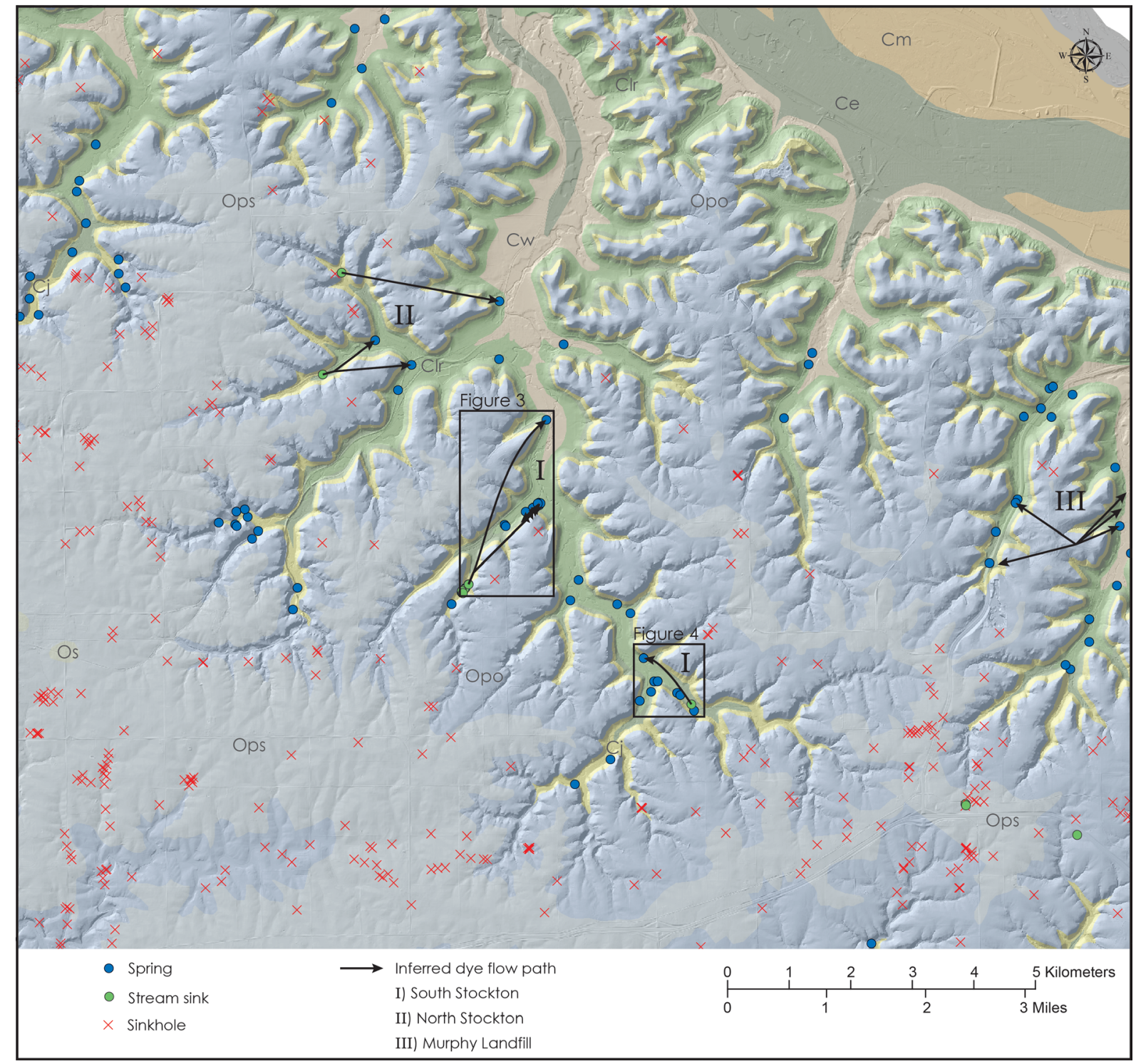

Figure 5. Project area dye traces. Paleozoic bedrock geology, karst features (springs, sinkholes, sinking streams), and the locations of dye trace investigations in the vicinity of the project area. Geologic map from Steenberg, 2014. 
wells and springs within an 8,500 meter (28,000 feet) radius of the project area (Figure 6).

A suite of parameters, including nitrate, chloride, chloride/bromide, tritium, and dissolved oxygen, were used to determine anthropogenic influence, generalized residence time, and potential conduit networks of the collected water samples using the following rationales.
In Minnesota, the use of agricultural fertilizers, the application of road salts for winter time deicing, and water softener effluent and can lead to elevated levels of nitrate and chloride in surface water and groundwater systems. Nitrate and chloride were used as geochemical indicators of recent human influence on groundwater using the following classification scheme. Nitrate concentrations greater than 1 part per million (ppm) are

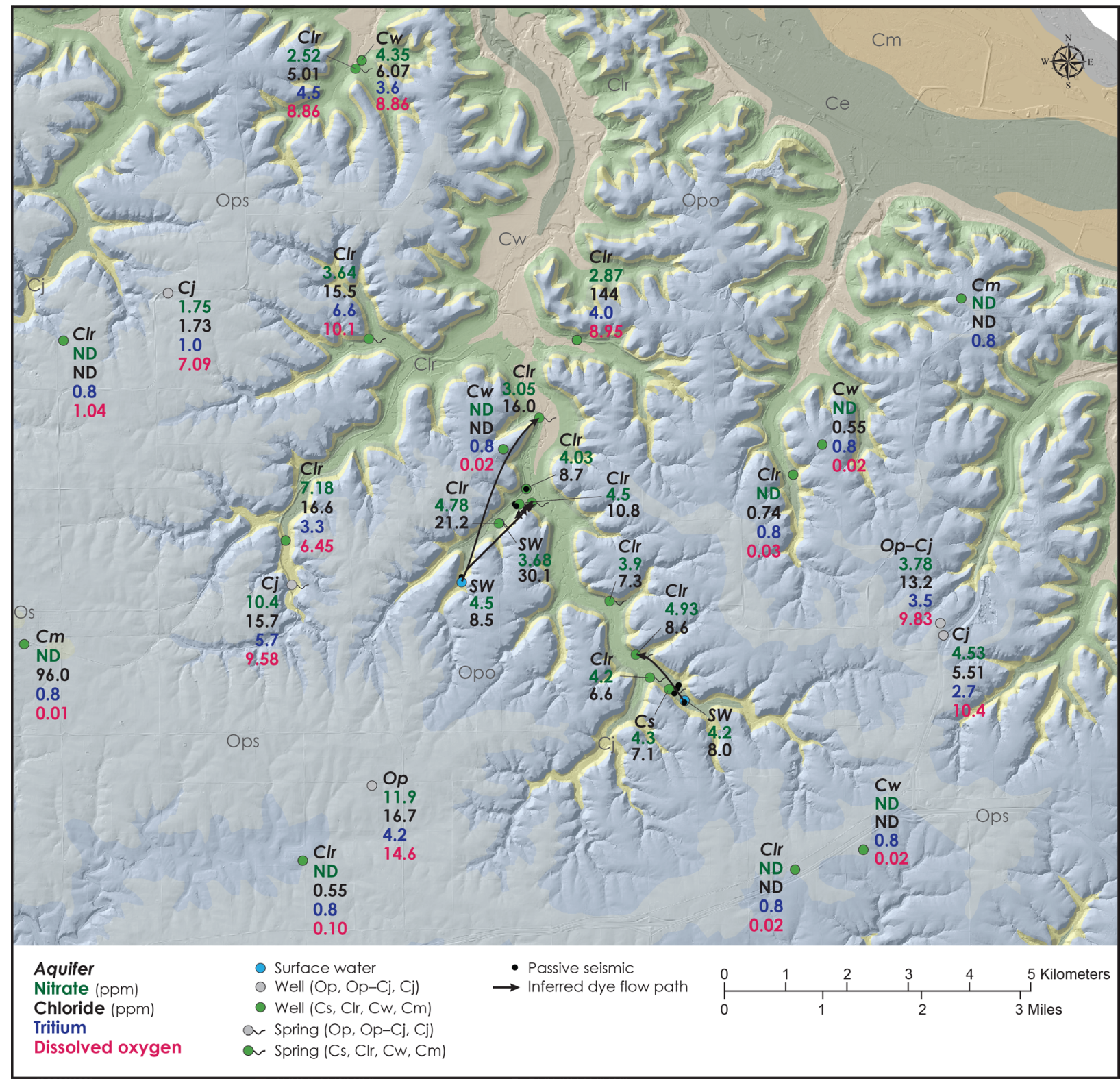

Figure 6. Project area water chemistry. Regional groundwater chemistry collected from Paleozoic aquifers located within 8,500 meters of the project area. Chemistry from wells completed in aquifers above the St. Lawrence Formation show anthropogenic influences. Near deeply incised valleys, the competency of the St. Lawrence as an aquitard is diminished, resulting in springs and wells with evidence of anthropogenic chemical signatures. Geologic map from Steenberg, 2014. 
greater than background conditions and possibly indicate that an aquifer has been impacted by activities on the land surface (Minn. Dept. of Health, 1998; Wilson, 2012). Nitrate concentrations greater than $3 \mathrm{ppm}$ indicate that an aquifer has been impacted by activities on the land surface (Minn. Dept. of Health, 1998).

Chloride concentrations greater than $5 \mathrm{ppm}$ can additionally be used to indicate that an aquifer has been impacted by activities on the land surface. In Minnesota, most aquifers with non-detectable tritium (residence time approximately $>70$ years) that are not mixed with residual brine typically have chloride concentrations less than 5 ppm (Petersen TA, unpublished analysis of data in the DNR County Atlas Database, 2017). Naturally elevated chloride levels can be distinguished using $\mathrm{Cl} / \mathrm{Br}$ ratios (Davis et al., 1998; Panno et al., 2006). In general, samples with chloride-to-bromide ratios below 300 are waters that have naturally elevated chloride.

Groundwater residence time is interpreted from the concentration of tritium. Atmospheric concentrations of tritium were greatly increased between 1953 and 1963 by atmospheric testing of nuclear weapons (Alexander and Alexander, 1989) allowing for estimation of residence time using tritium units (TU) present in a sample. The residence time of the water sample is adjectively described using the following schema.

- Recent: water entered the ground since about 1953 (8 to 15 TU).

- Mixed: water is a mixture of recent and vintage (greater than $1 \mathrm{TU}$ to less than $8 \mathrm{TU}$ ).

- Vintage: water entered the ground before 1953 (less than or equal to $1 \mathrm{TU}$ ).

Elevated dissolved oxygen (D.O.) values can be coupled with the parameters listed above to characterize conduit flow and aquifers with rapid vertical recharge. D.O. collected at wells located a distance from incised valleys typically show a bifurcated pattern, where they are anoxic below the St. Lawrence and oxic above. Wells and springs located within or in close proximity to incised valleys typically have elevated D.O. For this paper, D.O. values greater than $1 \mathrm{mg} / \mathrm{L}$ are considered oxic; values less than $1 \mathrm{mg} / \mathrm{L}$ are considered anoxic.

Groundwater collected from wells and springs located stratigraphically above the St. Lawrence in general show anthropogenic influences reflected by elevated nitrate and chloride, tritium ages $<70$ years, and oxygenated waters even at distances away from incised valleys (Figure 7, Table 1). These oxygenated waters are believed to reflect conduit networks that allow for rapid vertical recharge in a cascading scenario. Wells located at a distance from incised valleys and below the St. Lawrence typically have low nitrate, low anthropogenic chloride, non-detectable tritium, and are anoxic. Wells and springs located within or within close proximity to incised valleys generally have elevated nitrate, chloride, tritium, and/or dissolved oxygen. In this setting, wells typically do not have the full thickness of the St. Lawrence for protection or the St. Lawrence is compromised or absent. Our data further support the interpretation that the St. Lawrence is a competent aquitard under deep bedrock settings at distances from incised valleys. In proximity to incised valleys and under shallow bedrock conditions, the aquitard's ability to limit vertical flow is tenuous (Runkel et al., 2014). In this shallow setting, the St. Lawrence transitions from an aquitard to a pseudokarst aquifer.

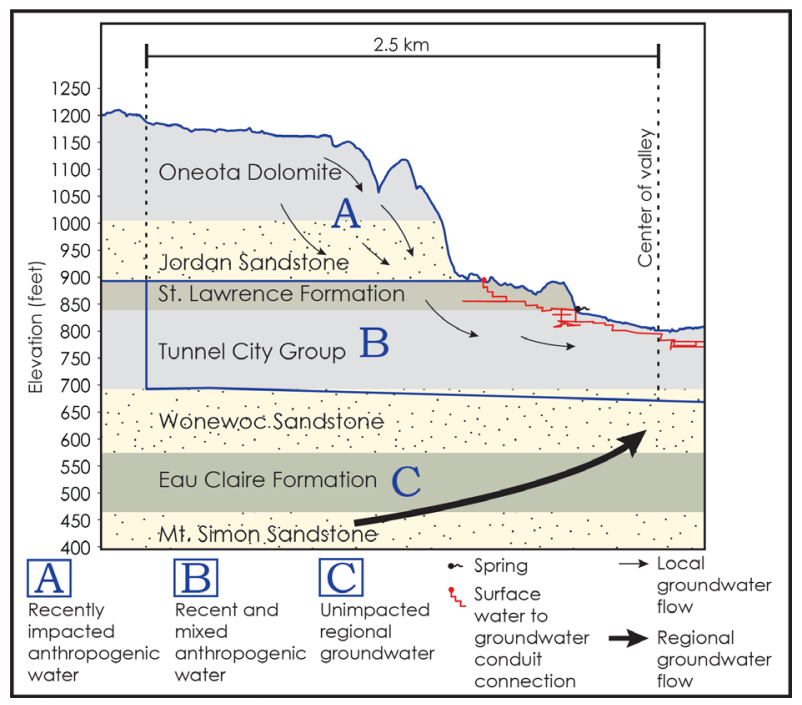

Figure 7. Generalized groundwater zones of influence of the project area. Groundwater from Zone $A$ is generally impacted by anthropogenic influences and has detectable recent tritium concentrations. Groundwater from Zone B generally shows mixed anthropogenic influences and has detectable tritium with mixed concentrations. Groundwater from Zone C shows no anthropogenic influence and has nondetectable tritium concentrations. 


\begin{tabular}{|c|c|c|c|c|c|c|c|c|c|c|}
\hline RELATEID & Formation & Nitrate-N & Chloride & $\begin{array}{l}\text { Dissolved } \\
\text { Oxygen } \\
(\mathrm{mg} / \mathrm{L})\end{array}$ & Tritium & Bromide & $\mathrm{Cl} / \mathrm{Br}$ & $\begin{array}{c}\text { Well } \\
\text { Completion } \\
\text { Depth } \\
\text { meters (ft) }\end{array}$ & $\begin{array}{l}\text { Distance } \\
\text { from center } \\
\text { of Valley } \\
(\mathrm{km})\end{array}$ & $\begin{array}{l}\text { Influence } \\
\text { Zone }\end{array}$ \\
\hline \multicolumn{11}{|l|}{ Surface Water } \\
\hline $85 \times 0000055$ & - & 4.5 & 8.5 & ns & ns & ND & - & - & 0.10 & B \\
\hline $85 \times 0000056$ & - & 4.2 & 8 & ns & ns & ND & - & - & within & B \\
\hline $85 \times 0000059$ & - & 3.68 & 30.1 & ns & ns & ND & - & - & within & B \\
\hline \multicolumn{11}{|l|}{ Spring } \\
\hline $85 A 0000331$ & $\mathrm{Cj}$ & 10.4 & 15.7 & 9.58 & 5.7 & 0.02 & 785 & - & 0.60 & A \\
\hline $85 A 0000356$ & Cs & 4.3 & 7.1 & ns & ns & ND & - & - & within & B \\
\hline $85 A 0000029$ & $\mathrm{Clr}$ & 4.93 & 8.6 & ns & ns & ND & - & - & within & B \\
\hline $85 A 0000370$ & $\mathrm{Clr}$ & 3.9 & 7.3 & ns & ns & ND & - & - & within & B \\
\hline $85 A 0000015$ & Clr & 3.05 & 16 & ns & ns & ND & - & - & within & B \\
\hline $85 A 0000054$ & $\mathrm{Clr}$ & 4.2 & 6.6 & ns & ns & ND & - & - & within & B \\
\hline $85 A 0000376$ & $\mathrm{Clr}$ & 4.78 & 21.2 & ns & ns & ND & & & within & B \\
\hline $85 \mathrm{~A} 0000014$ & $\mathrm{Clr}$ & 3.64 & 15.5 & 10.08 & 6.6 & 0.01 & 1550 & - & within & B \\
\hline $85 A 0000330$ & $\mathrm{Clr}$ & 2.52 & 5.01 & 8.86 & 4.5 & ND & - & - & within & B \\
\hline $85 \times 0000086$ & $\mathrm{Clr}$ & 4.5 & 10.8 & ns & ns & ND & - & - & within & B \\
\hline \multicolumn{11}{|l|}{ Well } \\
\hline 268925 & Ops-Opo & 11.9 & 16.7 & 14.6 & 4.2 & 0.0308 & 542 & $85(280)$ & 3.70 & A \\
\hline 219143 & Opo-Cj & 3.78 & 13.2 & 9.83 & 3.5 & 0.0135 & 978 & $91(300)$ & 0.90 & A \\
\hline 219147 & $\mathrm{Cj}$ & 4.53 & 5.51 & 10.39 & 2.7 & 0.0248 & 222 & $102(337)$ & 1.00 & A \\
\hline 107733 & $\mathrm{Cj}$ & 1.75 & 1.73 & 7.09 & 1 & 0.0183 & 95 & $100(330)$ & 1.20 & A \\
\hline 737943 & $\mathrm{Clr}$ & ND & ND & 0.02 & 0.8 & 0.0067 & - & $156(515)$ & 2.40 & C \\
\hline 564593 & $\mathrm{Clr}$ & ND & 0.55 & 0.1 & 0.8 & 0.007 & 79 & $164(540)$ & 4.90 & C \\
\hline 107601 & $\mathrm{Clr}$ & 7.18 & 16.6 & 6.45 & 3.3 & 0.0383 & 433 & 38 (125) & within & B \\
\hline 624709 & $\mathrm{Clr}$ & 4.03 & 8.7 & ns & ns & ND & & $28(95)$ & within & B \\
\hline 446822 & $\mathrm{Clr}$ & ND & 0.74 & 0.03 & 0.8 & 0.0068 & 109 & 51 (168) & within & B \\
\hline 780784 & $\mathrm{Clr}$ & ND & ND & 1.04 & 0.8 & 0.0053 & - & $152(500)$ & 1.00 & B \\
\hline 676724 & $\mathrm{Clr}$ & 2.87 & 144 & 8.95 & 4 & 0.0367 & 3924 & $29(96)$ & within & B \\
\hline 655838 & $\mathrm{CW}$ & ND & ND & 0.02 & 0.8 & 0.0067 & - & $198(650)$ & 2.50 & C \\
\hline 667277 & $\mathrm{CW}$ & ND & ND & 0.02 & 0.8 & 0.006 & - & 163 (537) & 0.20 & C \\
\hline 179226 & $\mathrm{CW}$ & ND & 0.55 & 0.02 & 0.8 & 0.0067 & 82 & 188 (618) & 0.60 & C \\
\hline 127880 & $\mathrm{CW}$ & 4.35 & 6.07 & 8.86 & 3.6 & 0.0136 & 446 & $28(95)$ & within & B \\
\hline 603060 & $\mathrm{Cm}$ & ND & 96 & 0.01 & 0.8 & 0.429 & 224 & 351 (1154) & 4.40 & C \\
\hline 554227 & $\mathrm{Cm}$ & ND & ND & 0 & 0.8 & 0.0087 & - & 328 (1077) & 0.50 & C \\
\hline
\end{tabular}

Table 1. Summary of groundwater and surface water chemistry presented in this paper. Summary of select anion and isotope data presented in this paper. Influence zones are linked to conceptual model presented in Figure 7. ND=not detected, ns=not sampled

Springs in the St. Lawrence and Lone Rock Formations with elevated anthropogenic signatures, short residence times, and elevated D.O. are likely a mixture of impacted upper stratigraphic aquifers and un-impacted groundwater from lower aquifers. Previous work and the work in this paper have shown anthropogenically impacted waters appear to flow vertically downward in a "stair step" like pattern through conduit networks that are in proximity to the valleys (Runkel et al., 2013; Barry et al., 2015; Runkel et al., in prep). Groundwater chemistry from springs emerging in the St. Lawrence and Lone Rock Formations suggests mixing of upper stratigraphic recent tritium aged water with elevated nitrate and chloride with unimpacted vintage tritium aged water with low nitrate and chloride. Vintage tritium age water likely reflects older far-field regional flow systems (Green et al., 2014). These mixtures typically create concentrations of nitrate in the $4-5 \mathrm{mg} / \mathrm{L}$ range, elevated chloride $>8 \mathrm{mg} / \mathrm{L}$, tritium values ranging from 1-7 TU, and D.O. concentrations similar to aerated surface waters $(8-10 \mathrm{mg} / \mathrm{L})$.

Up-gradient of the incised valleys, the St. Lawrence is a competent barrier to flow, with concentrations of nitrate, chloride, and tritium from wells cased below the St. Lawrence typically low and un-impacted.

Trend analysis of nitrate concentrations (1981 to present) from several St. Lawrence-Lone Rock springs in southeastern Minnesota shows steadily increasing nitrate levels (Runkel et al., 2014; unpublished analysis of Minnesota Department of Agriculture (MDA) spring 
chemistry). Nitrate concentrations from springs sampled in this study are similar to concentrations collected by the MDA from the same hydrostratigraphic unit at springs located elsewhere in southeastern Minnesota. Continuous nitrate monitoring at several of these springs shows that nitrate concentrations typically fluctuate less than $0.5 \mathrm{mg} / \mathrm{L}$ following recharge events.

\section{Passive Geophysical Results}

Horizontal to vertical spectral ratio analysis (HVSR) was conducted on data collected at eight locations within the project area using a tromograph. The analyzed data had readily perceptible peaks that likely represent the bedrock surface. However, it is possible that multiple peaks and side lobes apparent in the processed data collected at some of the stations represent an uneven bedrock surface or non-discernable Quaternary stratigraphy. Passive data was collected next to a well in the project area and compared to the results of the well log. For this control location, the passive interpretation estimated 15.2 meters ( 50 feet) to the bedrock surface relative to the 18.3 meters ( 60 feet) to the bedrock surface shown in the well construction $\log$.

At the discrete sinking stream point in the north valley, near $85 \mathrm{~B} 26$, the depth to bedrock was determined to be 6.4 meters (21 feet). Depth to bedrock estimates for the north valley transect suggest a relatively uniform valley shape, with bedrock at or near land surface at the toe of the slope from the valley walls increasing to 12.2-15.2 meters (40-50 feet) below ground surface in the center of the valley.

Depth to bedrock was determined to be 5.2 meters (17 feet) at the discrete sinking stream point (85B24) in the south valley. Depth to bedrock estimates for the south valley transect suggest an asymmetric valley shape, with bedrock at or near land surface at the toe of the slope from the valley walls increasing from 6.1 meters (20 feet) below ground surface on the south side of the valley to 9.1 meters (30 feet) below ground surface on the north side of the valley.

Constraining the depth to bedrock in these valleys is an important tool in these analyses. It aids in identifying the depth to subcrop locally since homesteads with water well records within the valley are rare. It also has implications for groundwater flow velocities since water may be sinking and traveling within the alluvium before entering the bedrock system.

\section{Conclusion}

Dye trace flow paths and groundwater velocities, local and regional water chemistry results, and estimated depth to bedrock determined from passive geophysics have assisted in further characterizing a southeastern Minnesota pseudokarst aquifer.

Minimum groundwater velocities recorded for these traces are consistent with values recorded in similar settings and further demonstrate that conduit networks in the siliciclastic St. Lawrence Formation in incised valley settings are connected to conduit networks in the underlying siliciclastic Lone Rock Formation. In shallow bedrock settings, these networks exhibit high to very high horizontal and vertical hydraulic conductivity within the relatively low permeability rock matrix. This elevated hydraulic conductivity allows anthropogenically influenced surface water and groundwater to migrate to deeper depths in these settings.

Springs emanating from Paleozoic aquifers in southeastern Minnesota provide perennial discharge of cool water to the abundant trout streams of the area. Documenting groundwater flow dynamics and geochemical trends of southeastern Minnesota's groundwater system through dye tracing, geochemical analysis and detailed geologic mapping provides information to water resource managers, planners, and fisheries managers to make more informed decisions on how to manage and protect resources. Increasing concentrations of nitrate in surface water and groundwater in southeastern Minnesota has the potential to increase nitrogen saturation in fish hatcheries and in streams. Supersaturation of nitrogen gas in hatcheries and in-stream can cause pathological changes and mortality in fish (Machado et al., 1987).

The data and approaches outlined in this document have improved our understanding of flow dynamics in the vicinity of south Stockton. Observations made in this paper are similar to those made by others and are enhancing the understanding of groundwater flow in southeast Minnesota.

\section{Acknowledgments}

The work presented in this report could not have occurred without the permission of Lois Ladewig and family, who graciously allowed access to their property and answered many questions about their fish hatchery and operations. Several members of the University of Minnesota Earth 
Sciences Department assisted with these traces. Sophie Kasahara performed sample analysis, and Betty Wheeler assisted with analytical results tracking. Dr. Val Chandler of the Minnesota Geological Survey graciously lent us the passive seismic equipment and performed the geophysical data analysis and interpretation. Dr. Tony Runkel of the Minnesota Geological Survey provided thoughtful discussion and review. Special thanks is given to Holly Johnson for her technical and graphical editing assistance.

\section{References}

Alexander SC, Alexander EC, Jr. 1989. Residence times of Minnesota groundwaters: Minnesota Academy of Sciences Journal, 55 (1): 48-52.

Barry JD, Green JA. 2015. REPORT on the 20142015 dye traces conducted in the vicinity of Stockton Minnesota. Winona County, MN. Retrieved from the University of Minnesota Digital Conservancy, http://hdl.handle. net/11299/184791.

Barry JD, Green JA, Steenberg JR. 2015. Conduit flow in the Cambrian Lone Rock Formation, Southeast Minnesota, U.S.A. In: Doctor DH, Land L, Stephenson JB, editors. 2015. Sinkholes and the Engineering and Environmental Impacts of Karst: Proceedings of the Fourteenth Multidisciplinary Conference, October 5-9, Rochester, Minnesota, published online by University of South Florida, Digital Collections, p. 31-42. Available at: http://digital.lib.usf.edu/ content/SF/S0/05/37/49/00001/K26-03300Conduit_Flow_in_the_Cambrian_Lone_Rock Formation_Southeast_Minne.pdf.

Barry JD. In prep. Geologic Atlas of Winona County, Minnesota, Minnesota Department of Natural Resources County Atlas.

Bauer EJ, Chandler VW. 2014. Data-base map: plate 1, Geologic Atlas of Houston County, Minnesota, Minnesota Geological Survey County Atlas C-33, 4 pls. scale 1:100,000.

Chandler VW, Lively RS. 2014. Evaluation of the horizontal-to-vertical spectral ratio (HVSR) passive seismic method for estimating the thickness of Quaternary deposits in Minnesota and adjacent parts of Wisconsin: Minnesota Geological Survey Open File Report 14-01, 52 p.

Dalgleish JB, Alexander EC, Jr. 1984. Hydrogeologic Investigation of the Proposed Expansion Site of the Winona County (Murphy) Landfill. Retrieved from the University of Minnesota Digital Conservancy, http://hdl.handle.net/11299/188262.
Davis SN, Whittemore DO, Fabryka-Martin J. 1998. Uses of chloride/bromide ratios in studies of potable water: Ground Water 36 (2): 338-350.

Green JA, Barry JD, Alexander EC, Jr. 2014. Springshed Assessment Methods for Paleozoic Bedrock Springs of Southeastern Minnesota. Report to the Legislative-Citizen Commission on Minnesota Resources. Minn. Dept. Natural Resources, St. Paul, MN, 48 p. Available from: http://files.dnr.state.mn.us/waters/groundwater section/mapping/springshed/springshed assessment_protocols.pdf.

Green JA, Luhmann AJ, Peters AJ, Runkel AC, Alexander EC, Jr., Alexander SC. 2008. Dye tracing within the St Lawrence confining unit in southeastern Minnesota. In: Yuhr L, Alexander EC, Jr., Beck B, editors. Sinkholes and the Engineering and Environmental Impacts of Karst, American Society of Civil Engineers, Proceedings GSP 183, p 477-484.

Green JA, Runkel AC, Alexander EC, Jr. 2012. Karst conduit flow in the Cambrian St Lawrence Formation, southeast Minnesota, USA. Carbonates and Evaporites 27 (2): 167-172.

Kempe S, Halliday WR. 1997. Report on the discussion on pseudokarast, in Proceedings of the 12th International Congress of Speleology, v. 6, Basel, Switzerland, Speleoprojects.

Lusardi BA, Adams RS, Hobbs HC. 2014. Surficial Geology, plate 3, Geologic Atlas of Houston County, Minnesota, Minnesota Geological Survey County Atlas C-33, 4 pls. scale 1:100,000.

Machado JP, Garling DL, Kevern NR, Jr., Trapp AL, Bell TG. 1987. Histopathology and the pathogenesis of embolism (gas bubble disease) in rainbow trout (Salmo gairdneri). Canadian Journal of Fisheries and Aquatic Sciences 44: 1985-1994.

Minnesota Department of Health. 1998. Guidance for mapping nitrate in Minnesota groundwater, $20 \mathrm{p}$.

Minnesota Department of Health. 2011. Rules Handbook- A Guide to the Rules Relating to Wells and Borings, Saint Paul, MN, accessed January 21, 2015 at http://www.health.state.mn.us/divs/eh/ wells/ruleshandbook/ruleshandbook.pdf.

Mossler JH. 2008. Paleozoic stratigraphic nomenclature for Minnesota: Minnesota Geological Survey Report of Investigations 65, 76 p., 1 pl.

Panno SV, Hackley KC, Hwang HH, Greenberg SE, Krapac IG, Landsberger S, O’Kelly DJ. 2006. Characterization and Identification of $\mathrm{Na}-\mathrm{Cl}$ Sources in Ground Water. Ground Water 44 (2): 176-187.

Runkel AC, Steenberg JR, Tipping RG, Retzler AJ. 2013. Physical hydrogeology of the groundwater- 
surface water system of southeastern Minnesota and geologic controls on nitrate transport and stream baseflow concentrations: Minnesota Geological Survey report delivered to the Minnesota Pollution control agency, Contract number B50858 (PRJ07522).

Runkel AC, Tipping RG, Alexander EC, Jr., Green JA, Mossler JH, Alexander SC. 2003. Hydrogeology of the Paleozoic bedrock in southeastern Minnesota. MGS Report of Investigations 61, 105p. 1 map in pocket.

Runkel AC, Tipping RG, Green JA, Jones PM, Meyer JR, Parker BL, Steenberg JR, Retzler AJ. 2014. OFR14-04, Hydrogeologic Properties of the St. Lawrence Aquitard, Southeastern Minnesota. Minnesota Geological Survey.

Runkel AC, Tipping RG, Meyer JR, Steenberg JR, Retzler AJ, Parker BL, Green JA, Barry JB, Jones PM. In prep. A multidisciplinary based conceptual model of a fractured bedrock aquitard: Improved prediction of aquitard integrity.

Steenberg JR. 2014. Bedrock Geology, plate 2, Geologic Atlas of Winona County, Minnesota, Minnesota Geological Survey County Atlas C-34, 4 pls., scale 1:100,000.

Underwood CA, Cooke ML, Simo JA, Muldoon MA. 2003. Stratigraphic controls on vertical fracture patterns in Silurian dolomite, northeastern Wisconsin. AAPG Bulletin 87 (1): 121-142.

Wilson JT. 2012. Water-quality assessment of the Cambrian-Ordovician aquifer system in the northern Midwest, United States: U.S. Geological Survey Scientific Investigations Report 20115229, $154 \mathrm{p}$. 